\title{
The Maluridae: Inferring Avian Biology and Evolutionary History from DNA Sequences
}

\section{Citation}

Joseph, Leo, Scott V. Edwards, and Alison J. McLean. 2013. “The Maluridae: Inferring avian biology and evolutionary history from DNA sequences." Emu 113 (3): 195-207. doi:10.1071/ MU12081. http://dx.doi.org/10.1071/MU12081.

\section{Published Version}

doi:10.1071/MU12081

\section{Permanent link}

http://nrs.harvard.edu/urn-3:HUL.InstRepos:11688778

\section{Terms of Use}

This article was downloaded from Harvard University's DASH repository, and is made available under the terms and conditions applicable to Open Access Policy Articles, as set forth at http:// nrs.harvard.edu/urn-3:HUL.InstRepos:dash.current.terms-of-use\#OAP

\section{Share Your Story}

The Harvard community has made this article openly available.

Please share how this access benefits you. Submit a story.

Accessibility 
$4{ }^{\mathrm{A}}$ Australian National Wildlife Collection, CSIRO Ecosystem Sciences, GPO Box 1700, Canberra, 5 ACT 2601, Australia

$6{ }^{\mathrm{B}}$ Museum of Comparative Zoology and Department of Organismic \& Evolutionary Biology, Harvard 7 University, 26 Oxford Street, Cambridge, MA, 02138, USA

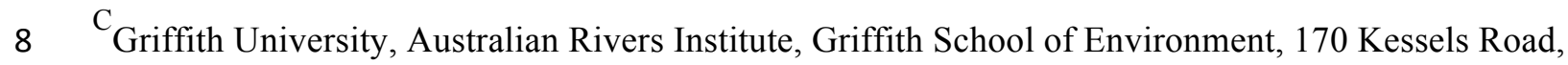
9 Nathan, QLD 4111, Australia

Abstract. The Australo-Papuan fairy-wrens, emu-wrens and grasswrens comprise the passerine family Maluridae. They have long been known for their spectacular plumages, remarkable behavioural ecology, and intriguing biogeography. The family has provided an ideal model with which to explore how phylogenetic and phylogeographic analyses of DNA sequence data can inform understanding of evolutionary history and present-day biology. We review what has been learned of the phylogeny of the group and the phylogeographic history of individual species. We conclude that there is now a strong framework within which to pursue the remaining species-level taxonomic issues, and to extend ecological and behavioural studies into a new era of more detailed genetic questions such as the role of gene-environment interactions in adaptation. We highlight some remaining examples of such questions and discuss how they might be addressed.

Introduction

The life history, systematics and biogeography of Australo-Papuan fairy-wrens, emu-wrens and grasswrens (Passeriformes: Maluridae) are a rich source of challenging evolutionary questions. Field, population-based studies that are reviewed in this suite of papers have illuminated these questions and such work will continue to do so. Complementing field studies has been a growing contribution from the fields of molecular systematics, phylogeography and population genetics all of which have undergone revolutions since the advent of DNA sequencing in the 1980s. Systematics is the study of how species are related to each other phylogenetically and how taxonomy can best express hypotheses of phylogenetic relationships. Similarly, looking within species, phylogeography is the DNA sequence-based study of the evolutionary forces that explain how genetic diversity within species is organized in space and time (Avise et al. 1987; Edwards et al. 2012). It has revolutionized 
understanding of evolutionary history within species. The Maluridae is almost unique in the foundation that molecular data have helped build for understanding of evolutionary history and ecological diversity within and among its species. Indeed, malurids are now a leading model for the integration of evolutionary and ecological data. Here we review how phylogenetic and phylogeographic analyses of DNA sequence data from the Maluridae have sharpened understanding of their relationships to other groups of birds as well as within and among its own member species. We provide a framework against which the spectacular behavioural ecology, reproductive biology, feeding ecology, behaviour, and morphology of malurids can be articulated in the accompanying papers.

After reviewing how the Maluridae are related to other passerine birds, we discuss how phylogenetic studies have informed understanding of the family's genera, species, populations and individuals. We will touch on questions of molecular systematics and historical biogeography, phylogeography, hybrid zones, population genetics, parentage and individual kinship.

\section{Who are the Maluridae and Where Do They Fit Among Passerines?}

The defining and distinguishing traits of the Maluridae (its diagnosis) and the genera and species that belong in it and those that do not (its circumscription) are not controversial. Morphological diagnoses of the Maluridae are in Schodde (1982), Sibley and Ahlquist (1985), Schodde and Mason (1999), Rowley (2001), and Rowley and Russell (1997, 2007). Diagnostic morphological traits include the interscapular gap of feathers and osteological characters of the humerus and palate. It has never been controversial that the Maluridae comprises the grasswrens Amytornis spp and the emu-wrens Stipiturus spp, both exclusively Australian, and the "true" fairywrens Malurus, Sipodotus, Clytomyias and Chenoramphus of Australia and New Guinea. Initial DNA sequence-based analyses of relationships across passerines therefore only used Malurus to represent the Maluridae (e.g., Barker et al. 2002, 2004; Ericson et al. 2002). These studies were not designed to provide independent, molecular tests of which genera belong in a natural group to be called the Maluridae. The point here is that analyses aiming to evaluate generic boundaries suggested by morphology do often surprise us. They can necessitate re-thinking of the membership of some higher groupings of birds. A spectacular, albeit non-malurid, example is Macgregor's Bird-of-Paradise Macgregoria pulchra, which is now known to be a honeyeater (Meliphagidae) (Cracraft and Feinstein 2000). Appropriately designed molecular studies of the Maluridae have now been done and unequivocally support the morphology-based diagnosis and circumscription of the Maluridae (Gardner et al. 2010; Driskell et al. 2011; Lee et al. 2012). Gardner et al. (2010) drew together the findings of all previous molecular studies and, with further data, affirmed that the Maluridae along with the Meliphagidae (honeyeaters) and the Acanthizidae (thornbills and their relatives) together make up one of the largest and indeed oldest radiations of Australo-Papuan birds, the superfamily 
Meliphagoidea. Among passerines, the Meliphagoidea in turn appears to have evolved from one of the earliest, major branches of the oscine tree in the Australia-New Guinea-New Zealand region.

Fundamentals of relationships among the three major groups of the Maluridae are again unremarkable. Phylogenetic analyses consistently and unambiguously recover the grasswrens, emuwrens and fairy-wrens as three natural groups, or clades, within the Maluridae. The grasswrens are clearly more divergent from the other two groups than the latter are to each other (Fig. 1). Therefore, the three clades are classified into two subfamilies, the Amytornithinae (grasswrens) and the Malurinae (emu-wrens and fairy-wrens). Within the Malurinae, the emu-wrens and fairy-wrens are formally recognized as the tribes Stipiturini and the Malurini, respectively (Driskell et al. 2011).

Figure 1

Relationships within genera have been more controversial and confusing. The debate has hinged on how four species endemic to New Guinea are related to Australian Malurus. The four are Orange-crowned Wren Clytomyias insignis, Wallace's Wren Sipodotus wallacii, Emperor Fairy-wren Malurus cyanocephalus, and Broad-billed Fairy-wren Chenoramphus grayi. Clytomyias had long been retained for the Orange-crowned Wren if only because of uncertainty in its relationship to Malurus and Stipiturus ( $c f$ Schodde 1992; Christidis and Schodde 1997). Alternative hypotheses placed Chenoramphus either in Malurus or with Clytomyias and Sipodotus in the sister group to Malurus (Schodde 1992; Christidis and Schodde 1997; Rowley and Russell 1997, 2007; Driskell et al. 2011; Lee et al. 2012; Fig. 1a, b). M. cyanocephalus had been placed in monotypic Todopsis. DNA studies (Driskell et al. 2011; Lee et al. 2012) agree that M. cyanocephalus, is the sister to all other species conventionally placed in Malurus. They also agree that Malurus so construed is sister to a group that includes Clytomyias and Chenoramphus (Fig.1a, b). Sipodotus has appears closest to Clytomyias (Driskell et al. 2011; Fig. 1b). Fortunately, therefore, genus-level stability has emerged. Consensus sees the biological merit of expanding Malurus to include M. cyanocephalus but to continue recognzing Clytomyias, Sipodotus and Chenoramphus

\section{A closer look at Malurus}

Malurus comprises nine Australian species: M. elegans, M. pulcherrimus, M. lamberti, M. amabilis, M. cyaneus, M. splendens, M. leucopterus, M. coronatus, M. melanocephalus), and two New Guinean ones (M. alboscapulatus, M. cyanocephalus). Not only is M. cyanocephalus sister to other Malurus as noted, but Australian M. leucopterus is sister to M. alboscapulatus and M. melanocephalus (Driskell et al. 2011; Lee et al. 2012). This scenario rejects a simple hypothesis of one episode of vicariance between Australia and New Guinea explaining the biogeographical history 
of the group. A more complex history of connections and breaks between the two land masses is suggested. The phylogeny implies multiple evolutionary gains and losses of traits such as fine, narrow bills of Australian species versus broader bills of New Guinean species (Schodde 1982). Driskell et al. (2011) argue that the Malurini originated in New Guinea not Australia; Lee et al. (2012) urged more quantitative analyses to test this.

Within Malurus several groupings have consistently been recovered in molecular studies and we discuss them sequentially.

\section{Chestnut-shouldered fairy-wrens (CSFW)}

CSFW comprises the Red-winged Fairy-wren M. elegans of south-western Australia, the Blue-breasted Fairy-wren M. pulcherrimus of drier south-western Australia and Eyre Peninsula, South Australia, the Lovely Fairy-wren M. amabilis of Cape York Peninsula, and the Variegated Fairy-wren M. lamberti having a vast range across inland, tropical northern and subtropical eastern Australia. CSFW has long been recognized as a natural group (Ford 1966; Harrison 1972; Schodde 1982; Rowley and Russell 1997, 2007). Molecular data affirm the CSFW's monophyly (Christidis and Schodde 1997; Driskell et al. 2011; Lee et al. 2012; McLean et al. 2012). Recognition of M. amabilis as a species distinct from M. lamberti (which was argued as late as Schodde 1982 and questioned by Cracraft 1986) poses questions that phylogenetic perspectives could inform. How and why have some Malurus species and not others evolved blue-backed females? How has M. lamberti evolved its high diversity of climatic environments and habitats, notwithstanding that all populations favour shrubby undergrowth? What are the dynamics at zones where two of its component forms meet? We now examine the CSFW and these questions more closely.

\section{Variegated Fairy-wren M. lamberti}

This species is the most widespread, climatically diverse and phenotypically variable malurid (Fig. 2). M. l. lamberti of wetter central eastern Australia inhabits tall, rank grass and shrubby understoreys. M. l. assimilis has a vast range across inland Australia in open shrublands and grasslands. M. l. rogersi occurs in rocky Triodia-clad hills in the Kimberley of north-western Australia. M. l. dulcis inhabits sandstone escarpments in the Top End of the Northern Territory. A fifth, M. l. assimilis-like form, M. l. bernieri, is recognized and inhabits Bernier and Dorre Islands off the Western Australian coast.

Molecular data have built a framework for understanding the evolution of this species' extraordinary diversity. McLean et al. (2012) showed it to be the result of a recent, explosive radiation such that mtDNA diversity does not yet closely match the geographically structured phenotypic 
diversity. The genomic basis of its climatic flexibility could be a rewarding study potentially illuminating how ecologically less flexible species might be managed under climate change.

Figure 2

McLean et al. (2012) found that for mtDNA M. l. lamberti was sister to a clade comprising all other subspecies of M. lamberti and M. amabilis. Pursuing this with data from the nuclear genome, however, they found that when up to four individuals per taxon per locus were used in analyses, the monophyly of all M. lamberti was recovered. The best defended hypothesis at present, therefore, combines Schodde's (1982) compelling morphological arguments with McLean et al.'s molecular analyses to recognize as sister species M. amabilis and M. lamberti (including M. l. dulcis, M. l. assimilis and M. l. rogersi). These studies caution that sampling multiple individuals per species as well as multiple genetic loci can yield a clearer, albeit often complex, picture of evolutionary history. The discordance here probably reflects different rates of evolution in the DNA of the mitochondria and nucleus. That is, genetic diversity in the nuclear genome of a common ancestor can be shared between diverging species for significantly longer than diversity in the mitochondrial genome.

\section{Origin and variation of the blue-backed phenotype across northern Australia}

M. l. rogersi, M. l. dulcis and M. amabilis share the unusual trait of blue-backed females and replace each other geographically across northern Australia. In the strongly sexually dimorphic species of Malurus in which alternate plumaged (breeding) males are colourful and female and basic (eclipse) male plumages are not, the blue dorsal plumage in females is clearly exceptional. Also, female M. l. dulcis and M. amabilis have white lores. An enduring puzzle, therefore, is the evolution and underlying biology of blue dorsal plumage in females of three tropical Australian taxa that are not each other's closest relatives.

Molecular data (Odeen et al. 2011; McLean et al. 2012; Lee et al. 2012) suggest answers to the problem and directions for closer study. Within the M. lamberti complex, M. l. dulcis and M. $l$. rogersi are apparently relatively recently evolved members of the group: their alleles are not reciprocally monophyletic with respect to each other or to other populations of lamberti (McLean et al. 2012); M. amabilis is sister to the whole M. lamberti group. Two hypotheses are suggested. First, blue dorsal plumage in females arose at least twice, once and probably earliest in M. amabilis and later in M. l. rogersi and M. l. dulcis. Conceivably, some facet of tropical light spectra in the birds' environments (Endler 1993) provides selective pressure for this. Alternatively, blue dorsal plumage in females may have been lost independently in most lineages of Malurus. The latter hypothesis is suggested because female plumages in M. cyanocephalus, which is sister to all other Malurus, and $C$. grayi, which is part of the sister group to Malurus, do involve blue on the head or dorsum. Homology or otherwise of the blue in females of all of these species (and white lores in M. l. dulcis and M. 
amabilis) should be tested to determine which evolutionary force(s) drove the loss, or gain, of blue dorsal female plumage in Australian species. Relevant here is the SWS1 opsin gene, which encodes a visual pigment sensitive to the ultraviolet-violet region of the visible spectrum and which fall into at least two discrete classes - violet sensitive and ultra-violet sensitive; only CSFW, M. cyaneus and $M$. splendens have the latter pigments (see Odeen et al. 2011). Certainly, a challenging study awaits to integrate phylogenetic relationships, light spectra in different environments across all Malurus, the SWS1 gene, and the birds' biology.

Intergradation between M. l. lamberti and M. l. assimilis in subtropical Australia.

Hybridization and introgression are common in birds and provide important windows into species interactions and speciation dynamics (Rheindt and Edwards 2011). Putative hybridization and zones of intergradation have been inferred between M. l. dulcis and M. l. assimilis (Harrison 1972), and M. l. rogersi and M. l. assimilis (Ford and Johnstone 1991) (reviewed in Schodde 1982). Mack's (1934) remark that "some examples of [M. l.] lamberti from the northern part of its range provide evidence of intergradation [with M. l. assimilis]", has long been the only basis that a zone of intergradation exists in south-east Queensland between M. l. lamberti and M. l. assimilis (Parker in Schodde 1975; Schodde 1982; Fig. 3). McLean et al. (2012) recovered M. l. lamberti as being highly divergent molecularly from M. l. assimilis (4.3\% divergence in mtDNA, or over 4 sites per 100 in this molecule, which is substantial), but noted that the Great Dividing Range essentially separates the two subspecies. Some work has explicitly assessed the Great Dividing Range's role as a barrier promoting vicariance (cf Pavlova et al. 2010, accepted). Closer study of this zone with new specimens revealed discordant patterns in mtDNA diversity, which was structured geographically (Fig. 3: right) and ; microsatellite loci, which were not. This implies that gene flow may still be substantial. Conflicting results between mtDNA and microsatellites are not uncommon (Caparroz et al. 2009; Rollins et al. 2012) and have often been explained through male-biased dispersal (Zink and Barrowclough, 2008). Sex-biased dispersal has not been studied in this species but is an unlikely explanation of these findings. In M. cyaneus, for example, males show natal philopatry whereas females are more likely to disperse (Double et al. 2005) and indeed female-biased dispersal is common in most species of birds (Greenwood, 1980). The conflict between mtDNA and nuclear loci here may result from differences in their population genetics and sensitivity to demographic changes, as well as challenges of deciphering evolutionary history from microsatellites. Evolution of microsatellites by their expansion and contraction is erratic and difficult to model (Zink and Barrowclough, 2008; Brito and Edwards 2009). Nuclear markers that more closely resemble the type of data used for mtDNA, such as sequence-based nuclear markers (Brito and Edwards 2009), may provide more insight into the history of intergradation in this group. 
Understanding how three species of CSFW have come to occur in south-western Australia has been a challenge to address at least in part through understanding how the species are related to each other. Yet the relationships among CSFW have proven difficult to resolve. This difficulty illustrates well the challenges that arise in reliably determining relationships among a close-knit group of species that have undergone rapid evolution (Fig.6 of McLean et al. 2012; Edwards et al. 2009; Lee et al. 2012). Fig. 4 shows alternative hypotheses. Christidis and Schodde (1997) and Lee et al. (2012) recovered M. elegans and M. pulcherrimus as sister species, the four CSFW thus being two simple sister species pairs. Conversely, Driskell et al. 2011 and McLean et al. (2012) found M. pulcherrimus to be sister to M. l. lamberti/M. amabilis and M. elegans sister to the other three. Clearly, further work is needed to discriminate among these hypotheses and build correlations between the evolutionary history of the birds and their habitats, for example.

The Blue group

Two primarily southern Australian species, the Superb M. cyaneus and Splendid Fairy-wrens M. splendens unremarkably form a sister species pair. They replace each other vicariously in southeastern mesic (M. cyaneus) and mostly drier western and inland (M. splendens) habitats. M. cyaneus has been extensively studied at the population level (see companion papers). Notable here are islandmainland comparisons of populations in M. cyaneus. This work first used morphology to affirm the prediction from ecological speciation theory that natural selection shapes adaptive divergence (Schlotfeldt and Kleindorfer 2006). Later work with molecular data then found highly restricted gene flow between the same island and mainland populations and presented concordant morphological and molecular evidence of evolutionary divergence occurring between the two populations (Dudaniec et al. 2011). Kleindorfer et al. (this issue) further examine this particular island-mainland comparison. geographical replacement of morphologically defined subspecies. They found general concordance among morphology and molecules. The exception was in inland eastern Australia where decoupled evolution in the two character sets had to be explained. They suggested that morphological 
local environmental conditions, or alternatively, mtDNA and plumage may have different rates of evolution.

\section{The Bicoloured group}

The bicoloured group comprises the White-shouldered Fairy-wren M. alboscapulatus of New Guinea (black-and-white males and geographically variable females), and White-winged Fairy-wren M. leucopterus (blue-and-white or black-and-white males) and Red-backed Fairy-wren $M$. melanocephalus (red-and-black males) of Australia. Adult male M. leucopterus over the species' vast inland Australian range have alternate or nuptial plumage that is blue with white scapulars, secondary wing-coverts and innermost secondaries. The populations isolated on Dirk Hartog and Barrow Islands (M. l. leucopterus and M. l. edouardi, respectively) have blue replaced by black. Evolution of differences between mainland and island populations has been addressed. Driskell et al. (2002) used mtDNA diversity across the entire range to derive a framework of the species' history. They found that the two island populations are not each other's closest relatives. Also, western mainland populations (with blue-and-white males) are more closely related to, and may have had relatively recent gene flow with, Dirk Hartog birds (black-and-white males) than to blue-and-white mainland populations further east. Two equally parsimonious hypotheses then could explain the shift between blue and black plumage: black plumage arose from blue convergently on the two islands, or black arose from blue and was followed by re-evolution of blue plumage in mainland Western Australia. Next, Doucet et al. (2004) studied a nuclear gene, MC1R, the melanocortin-1 receptor locus; work in a Neotropical bird, the Bananaquit Coereba flaveola, had shown that changes at a single nucleotide position in MC1R correlate perfectly with whether individual birds have the species' usual plumage or are melanic (all black) (Theron et al. 2001). Its relevance to melanic plumage polymorphism in various birds has since been studied (Mundy 2005; Mundy et al. 2004; Uy et al. 2009). Doucet et al. (2004) found in M. leucopterus that of 34 variable sites at the MC1R locus, 23 did not change the amino acid and 11 did. Five of the latter were perfectly associated with divergence in plumage phenotypes between mainland and island birds. They also argued on the basis of nanostructure of the feathers that black most likely evolved from blue. Driskell et al. (2010) then conducted a phylogenetically broader survey of $M C 1 R$ variation across Malurus generally and revisited feather nanostructure. They reasoned that across Malurus there is no correlation between $M C 1 R$ variation and whether plumage is blue or black. They further supported the hypothesis that there have been two independent transitions from blue to black in this species, and probably a third in the lineage leading to melanocephalus and alboscapulatus.

\section{The Purple-crowned Fairy-wren M. coronatus}

The Purple-crowned Fairy-wren M. coronatus of tropical northern Australia is of great interest given its unique biology within Malurus. Like other Malurus it is a cooperative breeder but 
unlike them has very low levels of extra pair paternity and is essentially monogamous (Kingma et al. 2009). It is a riparian specialist, restricted to Pandanus-dominated vegetation along the rivers across tropical savannas of northern Australia (Rowley and Russell 1997; Skroblin and Legge 2010). It lacks erectile ear-coverts and scapulars that other Malurus use in display and no courtship displays or petalcarrying have been recorded in it (Rowley and Russell 1997). It mostly lacks bright colour in its plumage, both sexes being predominantly grey and blue-tailed, males having the eponymous purplecrown and females having brown ear-coverts. It is also relatively large. Three phylogenetic analyses have each reached different conclusions. Historical perspectives on the bird's biology are perhaps most cautiously considered as unresolved, despite Kingma et al.'s (2009) analysis based on an allozyme study Christidis and Schodde (1997). Gardner et al. (2010) found it to be sister to the blue group (M. cyaneus and M. splendens). Driskell et al. (2011) found it weakly supported as sister to the chestnut-shouldered group. Lee et al. (2012; Fig. 1) in the most exhaustive analysis found it on a branch that diverged after M. cyanocephalus and before the rest of Malurus. We are left with two alternatives that need further testing. One is that the data analysed to date genuinely reflect early branching of the M. coronatus lineage. The other is that the times between speciation events involving M. coronatus were short. By that alternative, the data still lack the power to place the species reliably in a sequence of phylogenetic divergence.

\section{Stipiturus Emu-wrens}

Systematic issues concerning the three species of emu-wrens are few. They mainly concern the taxonomic question of whether the Mallee Emu-wren, S. mallee, isolated in the Murray Mallee of South Australia and Victoria should be treated as a separate species, which current usage favours, or as a subspecies either of the Rufous-crowned Emu-wren S. ruficeps widespread in the western and central arid zone, or the Southern Emu-wren S. malachurus of southern Australian heaths and swamps. Phylogenetic analyses (Donnellan et al. 2009; Lee et al. 2012) affirm S. mallee and. S. ruficeps are more closely related to each other than either is to S. malachurus and that contact between $S$. malachurus and $S$. mallee is secondary. We suggest that understanding the historical biogeography of how mallee came to be isolated in its present range is now of far more interest. Understanding that it is closest to $S$. ruficeps is a key step in that process. Among birds, it shares its unusual distribution with several other unrelated species such as the Red-lored Whistler Pachycephala rufogularis, the Black-eared Miner Manorina melanotis and the easternmost form of the Western Whipbird Psophodes nigrogularis complex.

Donnellan et al. (2009) studied a 281 base pair fragment of the mitochondrial cytochrome $b$ gene across the range of $S$. malachurus. Several major disjunctions highlighted the need for nDNA data to clarify some of the issues raised. Most notable were the separation of western and eastern 
populations generally and, within eastern Australia, the distinct position of the Kangaroo Island and Eyre Peninsula populations being separated from other eastern populations by nine substitutions.

\section{Amytornis Grasswrens}

Grasswrens, among Australia's most unique birds, are a particularly rich and, at least relative to Malurus, untapped source of systematic and biogeographical questions. Although much of their species-level taxonomic confusion has been resolved (e.g., Parker 1972; Schodde and Mason 1999; Black 2004; Black et al. 2009; Christidis et al. 2010), some debate remains for populations of the widespread Striated Grasswren A. striatus and the Thick-billed Grasswren A. modestus. Notwithstanding such debate, the genus comprises four species (A. housei - Black, A. woodwardi White-throated, A. dorotheae - Carpentarian, A. ballarae - Kalkadoon) found disjunctly in rocky Triodia-clad habitats across tropical northern Australia, one (A. barbatus - Grey) confined to the Lake Eyre and Bullo drainages of inland eastern Australia, and others (A. striatus -Striated, A. textilis Western, A. merrotsyi - Short-tailed, A. goyderi - Eyrean, A. modestus - Thick-billed, A. purnelli Dusky) in a diversity of habitats, (eucalypt-porcupine grass Triodia or chenopod shrublands, rocky Triodia-clad hills; desert dune shrublands) in arid and semi-arid habitats across drier inland Australia (see Schodde 1982; Rowley and Russell 1997 for details).

Phylogenetic relationships among grasswrens are now relatively well understood (Keast 1958; Christidis 1999; Christidis et al. 2008, 2010; Lee et al. 2012). Changing understanding of the positions of $A$. goyderi and A. merrotsyi are instructive as to how molecular data have discriminated between morphologically based alternative hypotheses. Keast (1958) considered A. goyderi closely related to two largely chenopod shrubland-based species, $A$. textilis and A. modestus, an ecologically coherent arrangement. Later studies aligned it with A. striatus (Parker et al. 1978; Schodde 1982; Rowley and Russell 1997). Molecular data (Christidis et al. 2010; Lee et al. 2012) favoured the former hypothesis although clarified that $A$. housei and $A$. ballarae are part of the group to which $A$. goyderi belongs. Reassessment of its morphology revealed pitfalls into which earlier morphological analyses had fallen (see discussion in Schodde and Mason 1999; Christidis 1999). Similarly, $A$. merrotsyi was long considered a subspecies of $A$. striatus partly because of its geographical proximity to that group (Condon 1951; Keast 1958; Parker 1982; Schodde 1982). Molecular data (Christidis 1999; Christidis et al. 2008, 2010; Lee et al. 2012) and reassessment of its morphology (Schodde and Mason 1999) have shown it to be not part of the striatus group although there is some residual uncertainty about its precise placement.

Biogeographically, debate has centred on whether the origins of Amytornis were in northern (Schodde 1982) or central (Keast 1961; Ford 1974, 1987) parts of the continent. Lee et al.'s (2012) 
analysis favoured a central origin. Christidis et al. (2010) concluded that there may have been an early division of Amytornis into a lignum-swamp clade and at least one lineage in Triodia-clad, rocky escarpments.

Within Amytornis, there are clear disparities between patterns of morphological and molecular divergence and Christidis et al . (2010) presented a detailed analysis. For example, the $2.6 \%$ mtDNA divergence between phenotypically distinct $A$. woodwardi and $A$. dorotheae closely matches the $2.1 \%$ between weakly differentiated subspecies of $A$. merrotsyi (cf Christidis et al. 2008, 2010). This warrants closer study because members of both pairs are clearly isolated genetically and geographically from each other.

Remaining areas of most interest to species-level taxonomy in Amytornis concern A. textilis and A. modestus (Black 2011a, b; Black et al. 2010) and the A. striatus group. A. striatus is extraordinarily widespread and has been difficult to sample well across its vast range. Questions needing resolution concern the relationships and structure of genetic diversity among the four main populations that currently comprise it: the Pilbara form $A$. s. whitei, its widespread western sand plain and eastern mallee populations often regarded together as the nominotypical subspecies $A$. s. striatus and the western Queensland isolate $A$. s. rowleyi. Austin et al. (in review) have studied mtDNA diversity in nearly all extinct and extant populations of $A$. modestus and A. textilis. They found evidence of past gene flow between the extant A. t. myall of eastern Australia and one or more of the now extinct south-western populations of $A$. textilis. This means that the extant population harbours a "ghost" lineage of genetic diversity more typical of a now extinct form.

\section{Time frames and detailed studies of biogeography of malurids}

Molecular data often may provide the only quantitative, if imperfect, window into the time frame of a particular radiation. Notably, molecular data have affirmed suggestions of earlier authors (e.g., Ford 1974; Schodde 1982) that the Australian radiations of Malurus (McLean et al. 2012), Stipiturus (Donnellan et al. 2009) and Amytornis (Christidis et al. 2010) coincide, given indicated error margins, with the Miocene aridification of the continent. This pattern is increasingly clear from molecular studies of Australian vertebrates (Byrne et al. 2008; Toon et al. 2012). Here, we review biogeographic patterns in two clades, the four CSFW species and the red-backed fairy wren $M$. melanocephalus, and show how molecular data provide insight into the role of later, Pleistocene diversification patterns. Such analyses are particularly relevant given the controversies about the role of the Pleistocene in having shaped present-day diversity in different continents (Klicka and Zink 1999; Johnson and Cicero 2004; Hewitt 2004; Byrne et al. 2008; D’Horta et al. 2011). 
Elsewhere, we will present a detailed biogeographical reconstruction of the chestnutshouldered fairy-wrens (CSFW) but we here present a summary (Fig. 5) of the findings, which were based on a subset of anonymous loci and introns used by Lee et al. (2012). Reconstruction of ancestral distributions suggests that dispersal and vicariance have both been vital in shaping the current distribution pattern in CSFWs (15 dispersal events, 6 vicariant events and 1 extinction event). Given a phylogeny in which $M$. elegans is sister to other CSFW, the analysis suggests that CSFWs originated in south-western Australian forests, followed by an early dispersal event to Eyre Peninsula. A vicariant event would have given rise to $M$. elegans and the ancestor of other CSFW during a period spanning the Plio-Pleistocene border, 2.5 million years ago (MYA) (highest posterior density interval (HPD) 1.2 - 3.9 MYA). South-western Australia is a region characterized by extreme endemicity and high species diversity (Myers et al. 2000; Hooper and Gioia 2004; Edwards et al 2007). A south-western endemic being sister to a suite of other species found elsewhere does not necessarily mean a south-western area of origin for the endemic (Ladiges et al. 2011, 2012). Certainly, south-western Australia is a region in which some present day species represent old differentiation events.

The estimated time of this initial vicariance (see also McLean et al. 2012, their Fig. 6) coincides with immense climatic change in Australia following the initiation of major oscillations between aridity and pluviality (Byrne et al. 2008). It also coincides with the late Pliocene aridification of the Nullarbor Plain between mesic south-western and south-eastern Australia. The role of the Nullarbor and its fringing xeric habitats as an important barrier to dispersal for birds during Pleistocene periods of aridity has been explored in other birds (Cracraft 1986; Toon et al. 2007) including malurids (Dolman and Joseph 2012).

The currently fragmented distribution of $M$. pulcherrimus suggests that when sea level was lowered at one or more Pleistocene glacial maxima, this species may have been more continuous across southern Australia; presumably, it has maintained ecological separation from M. elegans by habitat (Ford 1966; Schodde 1982) but the temporal dynamics of this are not well understood. Similarly fragmented distributions are known in other species (e.g., Western Yellow Robins Eopsaltria griseogularis) and divergence between such isolated populations has been argued to have occurred at several times in the Pleistocene since the early-mid Pleistocene (Dolman and Joseph 2012). 
The analysis also suggested a mid-Pleistocene vicariant event isolating the ancestors of $M$. amabilis in Cape York Peninsula and M. lamberti in eastern Queensland. Causative biogeographic barriers may have been the Black Mountain Corridor and the Burdekin Gap, across which significant population differentiation has been observed in birds (Joseph et al. 1995; Nicholls and Austin 2005; Kearns et al. 2011) and reptiles (Dolman and Moritz 2006; Schneider et al. 1998). Pertinent here is that M. amabilis and M. lamberti in eastern Australia are restricted to coastal mesic zones and habitats such as mangrove, grassland and wetlands, rarely penetrating more than eighty metres into rainforest (Schodde 1982).

Around 400,000 years ago (0-0.306 MYA, HPD 0-0.504 MYA) as Australia became a "dusty world" (Byrne et al. 2008), the analyses suggest that the M. lamberti lineage then expanded into the arid interior. This is consistent with recent Pleistocene range expansions across arid Australia for many species of birds and reptiles (see Table 1 of Byrne et al. 2008; Joseph and Omland 2009), leading to evolution of more arid-adapted lineages. Further biogeographic reconstruction of CSFW, especially within M. lamberti, is constrained by poorly resolved relationships among M. l. rogersi, $M$. l. dulcis and M. l. assimilis (McLean et al. 2012).

\section{Red-backed Fairywren: recent subspeciation across the Carpentarian barrier}

The Red-backed Fairy-wren M. melanocephalus ranges widely across northern Australia's subtropical and tropical grasslands and savannas. Two subspecies, M. m. melanocephalus and M. m. cruentatus, have been diagnosed by variation in the red colour of the birds' wings, back and scapulars. Broad intergradation between the two is reported in north-eastern Queensland (Schodde and Mason 1999; Higgins et al. 2001). Lee et al. (2008) performed multilocus phylogeographic analyses of the species. The study was designed to test the biogeographic predictions of this taxonomy and sampled broadly over four biogeographic areas (sensu Cracraft 1986): the Kimberley Plateau, the Top End/Arnhem Land, Cape York and Eastern Forests. This strategy spanned the Carpentarian Gap (or Barrier), a region today of dry, sparsely wooded plains south of the Gulf of Carpentaria and where the Pleistocene Lake Carpentaria periodically existed up to 8500 years ago on the Australian-New Guinea continental shelf (Chivas et al. 2001; Cook et al. 2012). This gap has variously influenced diversification in Australian species including numerous birds (Edwards 1993; Jennings and Edwards 2005; de Bruyn et al. 2004; Kearns et al. 2010; Toon et al. 2010). Overall, the signals from mtDNA and the nuclear genome similarly and strongly indicated that the major biogeographic break within this species occurred not between Cape York and the Eastern Forests in north-eastern Queensland as inferred from plumage variation but further west across the Carpentarian Gap. 
This study also estimated the time of divergence between lineages on either side of the

442 Carpentarian Gap. The results illustrate the need for data sets to be comparable across studies. Early

443 suggestions that North American sister species pairs diverged well before the Pleistocene $(2.4-0.01$

444 MYA) came from mitochondrial DNA, which evolves rapidly in birds, at a rate of about 2\% per MYA

445 (Lovette 2004). Although this conclusion was disputed (Cicero and Johnson 2004), mtDNA often

446 gives older divergences than sequence-based markers from the nuclear genome. It may not have been

447 surprising that estimates of divergence from nuclear genes between eastern and western lineages of $M$.

448 melanocephalus were very recent, around 0.3 MYA. This recent divergence also reflects, of course,

449 the divergence between forms that are very closely related, such as taxonomic subspecies. However,

450 other studies of divergence across the Carpentarian barrier, such as that between grassfinches

451 (Poephila), which are recognized taxonomically at the species level, also yield a very recent

452 divergence time of about 0.6 MYA (Jennings and Edwards 2005; Balakrishnan et al. 2010). Thus

453 nuclear genes from malurids and other birds across the Carpentarian Gap suggest divergences well

454 within the Pleistocene. Yet the estimates of divergence times from mitochondrial DNA can be deep,

455 particularly for Neotropical taxa (Weir and Schluter 2007; Miller et al. 2010; Weir and Price 2011;

456 Gutierrez-Pinto et al. 2012). Australian birds have much to contribute to the global inventory of

457 diversification times and the role of the Pleistocene, but it will be important that different studies use

458 the same set of markers by which to calibrate time.

\section{Conclusion}

We hope that we have shown an important role of molecular data in unravelling the interplay between the evolutionary history and present-day biology of malurids. We are confident that this has now reached the point where a solid framework is in place for the evolutionary relationships within the family. Questions remain, especially at the species and population levels, but much progress has been made. We take the opportunity to emphasize that this stage would not have been reached without the diverse resources provided by museum collections. Similarly, we stress that continued growth and diversification of those resources through collection of new kinds of specimens will enable areas such as gene-environment interactions in changing environments to be pursued more thoroughly. Odeen et al.'s (2011) work cited above on SWS1 opsin gene variation is a hint of where this work might go. Only then will we continue teasing apart history and present-day biology in developing a full understanding of the most remarkable birds that are the Maluridae. 

CSIRO Ecosystems Sciences for support. AM thanks members of the molecular ecology lab at Griffith University for help and support. Work in the lab of SVE was supported by grants from the US National Science Foundation. All authors are grateful to past and present Australian National Wildlife Collection (ANWC) staff, especially Alex Drew, Ian Mason, Rob Palmer, Dick Schodde and John Wombey, and ANWC associates Lynn Pedler and Alicia Toon for help with field work and for making tissues available. The manuscript was greatly improved by comments from Kate Buchanan, Andrew Cockburn, Chris Pavey, David Westcott and two anonymous reviewers We gratefully acknowledge all those whose work we have reviewed and the permit-granting authorities who allowed the collection of specimens on which so much of the work reviewed here was based.

\section{References}

Austin, J., Joseph, L., Pedler, L. and Black, A. In review. Uncovering cryptic evolutionary diversity in southern Australian arid zone birds: molecular systematics and phylogeography of the Western and Thick-billed Grasswrens (Passeriformes: Maluridae: Amytornis). Submitted to Conservation Genetics 18 December 2012.

Barker, F. K., G. F. Barrowclough, and Groth, J.G. (2002). A phylogenetic hypothesis for passerine birds: taxonomic and biogeographic implications of an analysis of nuclear DNA sequence data. Proceedings of the Royal Society of London. Series B: Biological Sciences 269, 295 308.

Barker F. K., A. Cibois, P. Schikler, J. Feinstein, and J. Cracraft. (2004). Phylogeny and diversification of the largest avian radiation. Proceedings of the National Academy of Sciences of the USA 101, 11040-11045.

Brito, P., and Edwards, S. V. (2009). Multilocus phylogeography and phylogenetics using sequencebased markers. Genetica 135, 439-455.

Black, A. B. (2004). The 'Immarna' grasswrens of R. C. Chandler: locality, habitat, identity and taxonomic implications. South Australian Ornithologist 34, 199-211. 
Black, A.B. (2011b). Western Australia, home of the Grass-Wren (Amytornis textilis). Amytornis 3, 112.

Black, A., Carpenter, G., and Pedler, L. (2009). Distribution and habitats of the thick-billed grasswren Amytornis textilis subspecies myall. South Australian Ornithologist 35, 161-177.

Black, A. B., Joseph, L., Pedler, L. P., and Carpenter, G. A. (2010). A taxonomic framework for interpreting evolution within the Amytornis textilis-modestus complex of grasswrens. Emu 110, 358-363.

Byrne, M., Yeates, D., Joseph, L., Kearney, M., Bowler, J., Williams,M. A. J., Cooper,S., Donnellan, S.C., Keogh, J. S., Leys,R., Melville, J., Murphy, D. J., Porch, N., and Wyrwoll, K.-H. (2008). Birth of a biome: insights into the assembly and maintenance of the Australian arid zone biota. Molecular Ecology 17, 4398-4417.

Chivas, A. R., Garcia, A., and van der Kaars, S. (2001). Sea-level and environmental changes since the last interglacial in the Gulf of Carpentaria, Australia: an overview. Quaternary International 83-85, 19-46.

Christidis, L. (1999). Evolution and biogeography of the Australian grasswrens Amytornis (Aves: Maluridae). Australian Journal of Zoology 47, 113-124.

Christidis, L., and Schodde, R. (1997). Relationships within the Australo-Papuan fairywrens (Aves: Malurinae): an evaluation of the utility of allozyme data. Australian Journal of Zoology $\mathbf{4 5}$, $113-129$.

Christidis, L., Horton, P., and Norman, J.A. (2008). Subspeciation in the short-tailed grasswren (Amytornis merrotsyi, Maluridae). Emu 108, 275-282.

Christidis, L., Rheindt, F.E., Boles, W.E., and Norman, J.A., (2010). Plumage patterns are good indicators of taxonomic diversity, but not of phylogenetic affinities, in Australian grasswrens Amytornis (Aves: Maluridae). Molecular Phylogenetics and Evolution 57, 868-877.

Condon, H.T. (1951). Notes on the birds of South Australia: occurrence, distribution and taxonomy. South Australian Ornithologist 20, 26-68.

Cook, B.D. (2012). Statistical phylogeographic tests of competing 'Lake Carpentaria hypotheses' in the mouth-brooding freshwater fish, Glossamia aprion (Apogonidae). Marine and Freshwater Research 63, 450-456.

Cracraft, J. (1986). Origin and evolution of continental biotas: speciation and historical congruence within the Australian avifauna. Evolution 40, 977-996. 
Cracraft, J., and Feinstein, J. (2000). What is not a bird of paradise? Molecular and morphological evidence places Macgregoria in the Meliphagidae and the Cnemophilinae near the base of the corvoid tree. Proceedings of the Royal Society of London. Series B: Biological Sciences 267, 233-241.

de Bruyn, M., Wilson, J. C., and Mather, P.B. (2004). Reconciling geography and genealogy: phylogeography of giant freshwater prawns from the Lake Carpentaria region. Molecular Ecology 13, 3515-3526.

D'Horta, F. M., Cabanne, G.S., Meyer, D., and Miyaki, C.Y. (2011). The genetic effects of Late Quaternary climatic changes over a tropical latitudinal gradient: diversification of an Atlantic Forest passerine. Molecular Ecology 20, 1923-1935.

Dolman, G., and Joseph, L., (2012). A species assemblage approach to comparative phylogeography of birds in southern Australia. Ecology and Evolution 2, 354-369.

Dolman, G., and Moritz C. (2006). A multi-locus perspective on refugial isolation and divergence in rainforest skinks (Carlia). Evolution 60, 573-582.

Donnellan, S.C., Armstrong, J., Pickett, M., Milne, T., Baulderstone, J., Hollfelder, T., and Bertozzi, T. (2009). Systematic and conservation implications of mitochondrial DNA diversity in emuwrens, Stipiturus (Aves: Maluridae). Emu 109, 143-152.

Double, M.C., Peakall, R., Beck, N.R., and Cockburn, A. (2005). Dispersal, philopatry, and infidelity: Dissecting local genetic structure in superb fairy-wrens (Malurus cyaneus). Evolution 59, 625-635.

Doucet, S. M., Shawkey, M.D., Rathburn, M.K., Mays, H.L., and Montgomerie, R. (2004). Concordant evolution of plumage colour, feather microstructure and a melanocortin receptor gene between mainland and island populations of a fairy-wren. Proceedings of the Royal Society of London. Series B: Biological Sciences 271, 1663-1670.

Driskell, A.C., Prum, R.O., and Pruett-Jones, S. (2010). The evolution of black plumage from blue in Australian fairy-wrens (Maluridae): genetic and structural evidence. Journal of Avian Biology 41, 505-514.

Driskell, A.C., Pruett-Jones, S., Tarvin, K.A., and Hagevik, S. (2002). Evolutionary relationships among blue- and black-plumaged populations of the white-winged fairy-wren (Malurus leucopterus). Australian Journal of Zoology 50, 581-595. 
Driskell A.C., Norman J.A., Pruett-Jones S., Mangall E., Sonsthagen S., and Christidis, L. (2011). A multigene phylogeny examining evolutionary and ecological relationships in the Australopapuan wrens of the subfamily Malurinae (Aves). Molecular Phylogenetics and Evolution 60 , 480-485.

Dudaniec, R., Schlotfeldt , B., Bertozzi, T., Donnellan, S.C., and Kleindorfer, S. (2011). Genetic and morphological divergence in island and mainland birds: informing conservation priorities. Biological Conservation 144, 2902-2912.

Edwards, D.L., Roberts, J.D., and Keogh, J.S. (2007). Impact of Plio-Pleistocene arid cycling on the population history of a southwestern Australian frog. Molecular Ecology 16, 2782-2796.

Edwards, S. V. (1993). Long-distance gene flow in a cooperative breeder detected in genealogies of mitochondrial DNA sequences. Proceedings of the Royal Society of London. Series B. Biological Sciences 252, 177-185.

Edwards, S. V. (2009). Is a new and general theory of molecular systematics emerging? Evolution 63, 1-19.

Edwards, S. V., Cameron Devitt, S., and Fujita, M. (2012). Phylogeography. In Encyclopedia of Theoretical Ecology’. (Eds A. Hastings and L. Gross) pp. 557-565. (University of California Press, Berkeley).

Endler, J. A. (1993). The colour of light in forests and its implications. Ecological Monographs 63, 127.

Ericson, P. G. P., Christidis, L., Cooper, A., Irestedt, M. Jackson, J., Johansson, U.S., and Norman, J.A. (2002). A Gondwanan origin of passerine birds supported by DNA sequences of the endemic New Zealand wrens. Proceedings of the Royal Society of London. Series B: Biological Sciences 269, 235-241

Ford J. (1966). Taxonomy and variation of the chestnut-shouldered wrens of Western Australia. Emu. 66, $47-57$.

Ford J. (1974). Speciation in Australian birds adapted to arid habitats. Emu 74,161-168.

Ford J. (1987). Minor isolates and minor geographical barriers in avian speciation in continental Australia. Ети 87, 90-102.

Ford, J., Johnstone, R.E. (1991). Hybridisation between Malurus lamberti rogersi and Malurus lamberti assimilis in North-western Australia. Етu 91, 251-254. 
Gardner, J.L., Trueman, J.W.H., Ebert, D., Joseph, L., and Magrath, R.D. (2010). Phylogeny and evolution of the Meliphagoidea, the largest radiation of Australasian songbirds. Molecular Phylogenetics and Evolution 55, 1087-1102.

Greenwood, P.J., (1980). Mating systems, philopatry and dispersal in birds and mammals. Animal Behaviour 28, 1140-1162.

Gutierrez-Pinto, N., A. M. Cuervo, J. Miranda, J. L. Perez-Eman, R. T. Brumfield, and C. D. Cadena. (2012). Non-monophyly and deep genetic differentiation across low-elevation barriers in a Neotropical montane bird (Basileuterus tristriatus; Aves: Parulidae). Molecular Phylogenetics and Evolution 64, 156-165.

Harrison, C.J.O. (1972). A re-examination of the chestnut-shouldered wren complex of Australia. Bulletin of the British Museum of Natural History (Zoology) 21, 313-328.

Hewitt, G.M. (2004). Genetics consequences of climatic oscillations in the Quaternary. Philosophical Transactions of the Royal Society B: Biological Sciences 359, 183-195.

Hopper, S., and Gioia, P. (2004). The Southwest Australian floristic region: evolution and conservation of a global hot spot of biodiversity. Annual Reviews in Ecology, Evolution and Systematics 35, 623-50.

Jennings, W.B., and Edwards, S.V. (2005). Speciational history of Australian grass finches (Poephila) inferred from thirty gene trees. Evolution 59, 2033-2047.

Johnson, N.K., and Cicero, C. (2004). New mitochondrial DNA data affirm the importance of Pleistocene speciation in North American birds. Evolution 58, 1122-1130.

Joseph, L., and Omland, K. E. (2009). Phylogeography: its development and impact in AustraloPapuan ornithology with special reference to paraphyly in Australian birds. Emu 109, 1-23.

Kearns, A.M., Joseph, L., Edwards, S.V., and Double, M.C. (2009). Inferring the phylogeography and evolutionary history of the splendid fairy-wren Malurus splendens from mitochondrial DNA and spectrophotometry. Journal of Avian Biology 40, 7-17.

Kearns, A., Joseph, L., and Cook, L. (2010). The impact of Pleistocene climatic and landscape changes on Australian birds: a test using the pied butcherbird (Cracticus nigrogularis). Emu 110, 285-295.

Keast, J.A. (1958). Speciation in the genus Amytornis Stejneger (Passeres: Muscicapidae, Malurinae) in Australia. Australian Journal of Zoology 6, 33-52. 
Keast, J.A. (1961). Bird speciation on the Australian continent. Bulletin of the Museum of Comparative Zoology, Harvard 123, 303-495.

Kingma, S.A., Hall, M., Segelbacher, G., and Peters, A. (2009). Radical loss of an extreme extra-pair mating system. BMC Ecology 2009 9,15.

Klicka, J., and Zink, R. M. (1999). Pleistocene phylogeographic effects on avian evolution. Proceedings of the Royal Society of London. Series B: Biological Sciences 266, 695-700.

Ladiges, P., Parra-O., C., Gibbs, A., Udovicic, F., Nelson, G., and Bayly, M. (2011). Historical biogeographical patterns in continental Australia: congruence among areas of endemism of two major clades of eucalypts. Cladistics 27, 29-41.

Ladiges, P., Bayly, M., and Nelson, G. (2012). Searching for ancestral areas and artifactual centers of origin in biogeography: with comment on east-west patterns across southern Australia. Systematic Biology 61, 703-708.

Lee, J.Y., and Edwards, S.V. (2008). Divergence across Australia's Carpentarian barrier: statistical phylogeography of the red-backed fairy wren (Malurus melanocephalus). Evolution $\mathbf{6 2}$, 2953-3192.

Lee, J.Y., Joseph, L., and Edwards, S.V. (2012). A species tree for the Australo-Papuan fairywrens and allies. Systematic Biology 61, 253-271.

Liu, L. (2008). BEST: Bayesian estimation of species trees under the coalescent model. Bioinformatics 24, 2542-2543.

Lovette, I. (2004). Mitochondrial dating and mixed support for the ' $2 \%$ rule' in birds. Auk 121, 1-6.

Mack, G. (1934). A revision of the genus Malurus. Memoirs of the National Museum of Victoria 8 , 100-125.

McLean, A.J., Toon, A., Schmidt, D.J., Joseph, L., and Hughes, J.M. (2012). Speciation in chestnutshouldered fairy-wrens (Malurus spp.) and rapid phenotypic divergence in variegated fairywrens (Malurus lamberti): A multilocus approach. Molecular Phylogenetics and Evolution 63, 668-378.

Miller, M. J., Bermingham, E., Klicka, J., Escalante, P., and Winker, K. (2010). Neotropical birds show a humped distribution of within-population genetic diversity along a latitudinal transect. Ecology Letters 13, 576-586. 
Mundy, N.I. (2005). A window on the genetics of evolution: MC1R and plumage colouration in birds. Proceedings of the Royal Society of London. Series B: Biological Sciences 272, 16331640 .

Mundy, N. I., Badcock, N. S., Hart, T., Scribner, K., Janssen, K., and Nadeau, N. J. (2004). Conserved genetic basis of a quantitative plumage trait involved in mate choice. Science $\mathbf{3 0 3}$, $1870-1873$.

Myers, N., Mittermeier, R.A., Mittermeier, C.G., da Fonseca, G.A.B., and Kent, J., (2000). Biodiversity hotspots for conservation priorities. Nature 403, 853-858.

Nicholls, J. A., and Austin, J. J. (2005). Phylogeography of an east Australian wet-forest bird, the satin bowerbird (Ptilonorhynchus violaceus), derived from mtDNA, and its relationship to morphology. Molecular Ecology 14, 1485-1496.

Odeen, A., Pruett-Jones, S., Driskell, A.C., Armenta, J.K., and Hastad, O. (2011). Multiple shifts between violet and ultraviolet vision in a family of passerine birds with associated changes in plumage coloration. Proceedings of the Royal Society of London. Series B: Biological Sciences 279, 1269-1276

Parker, S.A. (1972). Remarks on the distribution and taxonomy of the grasswrens Amytornis textilis, modestus and purnelli. Emu 72, 157-166.

Parker, S.A. (1982). Notes on Amytornis striatus merrotsyi Mellor, a subspecies of the striated grasswren inhabiting the Flinders Ranges. South Australian Ornithologist 29, 13-16.

Parker, S.A., May, I., and Head, W. (1978). Some observations on the Eyrean Grasswren Amytornis goyderi (Gould, 1875). Records of the South Australian Museum 17, 361-371.

Pavlova, A., Walker, F.M., van der Ree, R., Cesarini, S., and Taylor, A.C. (2010). Threatened populations of the Australian squirrel glider (Petaurus norfolcensis) show evidence of evolutionary distinctiveness on a Late Pleistocene timescale. Conservation Genetics 11, 23932407.

Pavlova, A., Amos, J.N., Joseph, L., Loynes, K., Austin,J., Keogh, J.S., Stone, G.N., Nicholls, J.A., and Sunnucks,P. Accepted with revision. Perched at the cyto-nuclear crossroads: divergent mitochondrial lineages correlate with environment in the face of ongoing nuclear gene flow in an Australian bird. Accepted with revision Evolution, September 2012.

Rheindt, F., and Edwards, S. V. (2011). Genetic introgression: an integral but neglected component of speciation in birds. Auk 128, 620-632. 
Rollins, L.A., Svedin, N., Pryke, S.R., and Griffith, S.C., (2012). The role of the Ord Arid Intrusion in the historical and contemporary genetic division of long-tailed finch subspecies in northern Australia. Ecology and Evolution 2, 1208-1219.

Ronquist, F., and Heulsenbeck, J.P. (2003). Mr Bayes 3: Bayesian phylogenetic inference under mixed models. Bioinformatics 19, 1572-1574.

Rowley, I. (2001). Family Maluridae Australopapuan fairy-wrens, emu-wrens and grasswrens. In 'Handbook of Australian, New Zealand and Antarctic Birds. Tyrant-flycatchers to Chats. Volume 5'. (Eds P.J. Higgins, J.M. Peter, and W.K. Steele) pp 257-260. (Oxford University Press, Melbourne).

Rowley I., and Russell, E. (1997). 'Fairy-wrens and Grasswrens'”. (Oxford University Press Inc., New York)

Rowley I., and Russell, E. (2007). Family Maluridae. In 'Handbook of the Birds of the World Volume 12. Picathartes to Tits and Chickadees'. in (Eds J. del Hoyo, A.A. Elliott, and D.A. Christie) pp 490-531. (Lynx Edicions, Barcelona).

Schlotfeldt, B.E., and Kleindorfer, S. (2006). Adaptive divergence in the Superb Fairy-wren (Malurus cyaneus): a mainland versus island comparison of morphology and foraging behaviour. Emu 106, 309-319.

Schneider, C.J., Cunningham, M., and Moritz, C. (1998). Comparative phylogeography and the history of endemic vertebrates in the Wet Tropics rainforests of Australia. Molecular Ecology 7, 487-498.

Schodde, R. (1975). 'Interim List of Australian Birds. Passerines'. (RAOU, Melbourne).

Schodde, R. (1982). 'The Fairy-Wrens: A Monograph of the Maluridae.' Illustrated by R. Weatherly. (Lansdowne Editions, Melbourne).

Schodde, R., Mason, I.J., (1999). 'The Directory of Australian birds. A Taxonomic and Zoogeographic Atlas of the Biodiversity of Birds in Australia and Its Territories. Passerines.' (CSIRO Publishing, Melbourne).

Sibley, C. G., and J. E. Ahlquist. (1990). 'Phylogeny and Classification of Birds: A Study in Molecular Evolution.' (Yale University Press, New Haven).

Skroblin, A., and Legge, S. (2010). The distribution and status of the western subspecies of the Purple-crowned Fairy-wren (Malurus coronatus coronatus). Emu 110, 339-347. 
Theron, E., Hawkins, K., Bermingham, E., Ricklefs, R. E., and Mundy, N. I. (2001). The molecular basis of an avian plumage polymorphism in the wild: a melanocortin-1-receptor point mutation is perfectly associated with the melanic plumage morph of the bananaquit, Coereba flaveola. Current Biology 11, 550-557.

Toon, A., P. B. Mather, A. M. Baker, K. L. Durrant, and J. M. Hughes. (2007). Pleistocene refugia in an arid landscape: analysis of a widely distributed Australian passerine. Molecular Ecology 16, 2525-2541.

Toon, A., Hughes, J., and Joseph, L. (2010). Multilocus analysis of honeyeaters (Aves: Meliphagidae) highlights the spatio-temporal heterogeneity in the influence of biogeographic barriers in the Australian monsoonal zone. Molecular Ecology 19, 2980-2994.

Toon, A., Austin, J., Dolman, G., Pedler, L., and Joseph, L. (2012). Evolution of arid zone birds in Australia: leapfrog distribution patterns and mesic-arid connections in quail-thrush. Molecular Phylogenetics and Evolution 62, 286-295.

Uy, J.A.C., Moyle, R.G., Filardi, C., and Cheviron, Z.A. (2009). Difference in plumage color used in species recognition between incipient species is linked to a single amino acid substitution in the melanocortin-1 receptor. American Naturalist 174, 244-254.

Weir, J. T., and Schluter, D. (2007). The latitudinal gradient in recent speciation and extinction rates of birds and mammals. Science 315, 1574-1576.

Weir, J. T., and Price, M. (2011). Andean uplift promotes lowland speciation through vicariance and dispersal in Dendrocincla woodcreepers. Molecular Ecology 20, 4550-4563.

Yu, Y., Harris AJ, He X-J. (2010). S-DIVA (Statistical Dispersal-Vicariance Analysis): a tool for inferring biogeographic histories. Molecular Phylogenetics and Evolution 56, 848-850

Yu, Y., Harris, A.J., He, X.J., 2011. RASP (Reconstruct Ancestral State in Phylogenies) 2.0b. Available at http://mnh.scu.edu.cn/soft/blog/RASP. Accessed 18 September 2012.

Zink, R.M., (2010). Drawbacks with the use of microsatellites in phylogeography: the song sparrow Melospiza melodia as a case study. Journal of Avian Biology 41, 1-7.

Zink, R. M., and G. F. Barrowclough. (2008). Mitochondrial DNA under siege in avian phylogeography. Molecular Ecology 17, 2107-2121. 


\section{Figure Captions}

Fig. 1. (a) Species tree of the Maluridae from Lee et al. (2012). Species names with asterisks indicate those depicted in figures to the right, in order from top to bottom. Prepared by Angela Frost. Bird figures by Peter Marsack as in Rowley and Russell (1997). Amytornis woodwardi and Sipodotus wallacei were not available for inclusion but see Fig. 1 (b). Reproduced with permission. (b) Maximum likelihood tree for the Malurinae from Driskell et al. (2011). Numbers at the nodes are in the order of: maximum parsimony bootstrap value/maximum likelihood bootstrap value/Bayesian posterior probability. Bootstrap values and posterior probabilities $>98 \%$ are indicated by $*$ and a dash denotes the node was not present in the bootstrap tree. Reproduced with permission. Note that both trees were used to develop arguments that Chenoramphus should be retained for $M$. grayi/M. campbelli. See text for details.

Fig. 2. Distribution of the widespread Variegated Fairy-wren M. lamberti and its subspecies, and the Lovely Fairy-wren M. amabilis, redrawn from Schodde and Mason (1999). Hatching indicates putative zones of intergradations discussed in the text.

Fig. 3. Left: Phylogenetic relationships of M. l. assimilis (Clade 1) and M. l. lamberti (Clade 2) estimated in MrBayes v3.1.2 (Ronquist and Huelsenbeck 2003) based on Bayesian inference from unique mitochondrial ND2 haplotypes (sample size per haplotype if $>1$ shown in parentheses). LaAs specimen codes in bold are from the M. l. lamberti-M. l. assimilis zone of intergradations between the two (see map at right). LQ and LN are shorthand for samples of the species M. lamberti from Queensland and New South Wales. Maximum parsimony, posterior probabilities and maximum likelihood bootstrap values are indicated at the nodes. An asterisk represents values less than 85 / 0.85 / 85 respectively. Right: Central eastern Australian distribution of M. l. lamberti (white circles), M. l. assimilis (black) and zone of morphological intergrades (grey, between dashed lines) based on examination of all available specimens. 
Fig. 4. Alternative hypotheses of relationships among CSFW from (a) Lee et al. (2012) inferred using BEST from 1 mitochondrial gene, 5 anonymous nuclear loci, 5 nuclear introns and 7 nuclear exons; numbers on branches indicate posterior probabilities, and (b) Driskell et al. (2011) using maximum likelihood from four mitochondrial genes and three nuclear introns; numbers at the nodes are in order of: maximum parsimony bootstrap value / maximum likelihood bootstrap value / Bayesian posterior probability. See text for discussion.

Fig. 5. Inference of ancestral distributions of CSFW as implemented in RASP (Reconstruct Ancestral Ancestral State in Phylogenies) v 2.0 (Yu et al. 2011) by Bayesian binary MCMC (BBM) analysis. BBM offers a statistical procedure for inferring states, including geographic distributions, at ancestral nodes using a full hierarchical Bayesian approach (Ronquist 2004). Distributional regions are colour coded and were assigned a priori based on known distributions (shown on map); undetermined distributions are shaded black. Seven geographical regions that were used in the analysis are shown on the map as $\mathrm{A}$ to $\mathrm{H}$ (sensu Cracraft 1991). Pie charts at nodes of the tree above the map show relative probabilities of alternative ancestral distributions; the inset shows the most likely states at nodes. The outgroup, M. splendens melanotus, occurs in two of the regions occupied by M. l. assimilis (E and $F$ ) and was coded (EF). Further division of region $E$ did not alter marginal probabilities at the nodes. 25,000 trees previously produced by BEST v2.3 (Liu 2008) were loaded and the analysis was run for 100,000 cycles using 30 chains with the maximum number of areas kept at seven. 


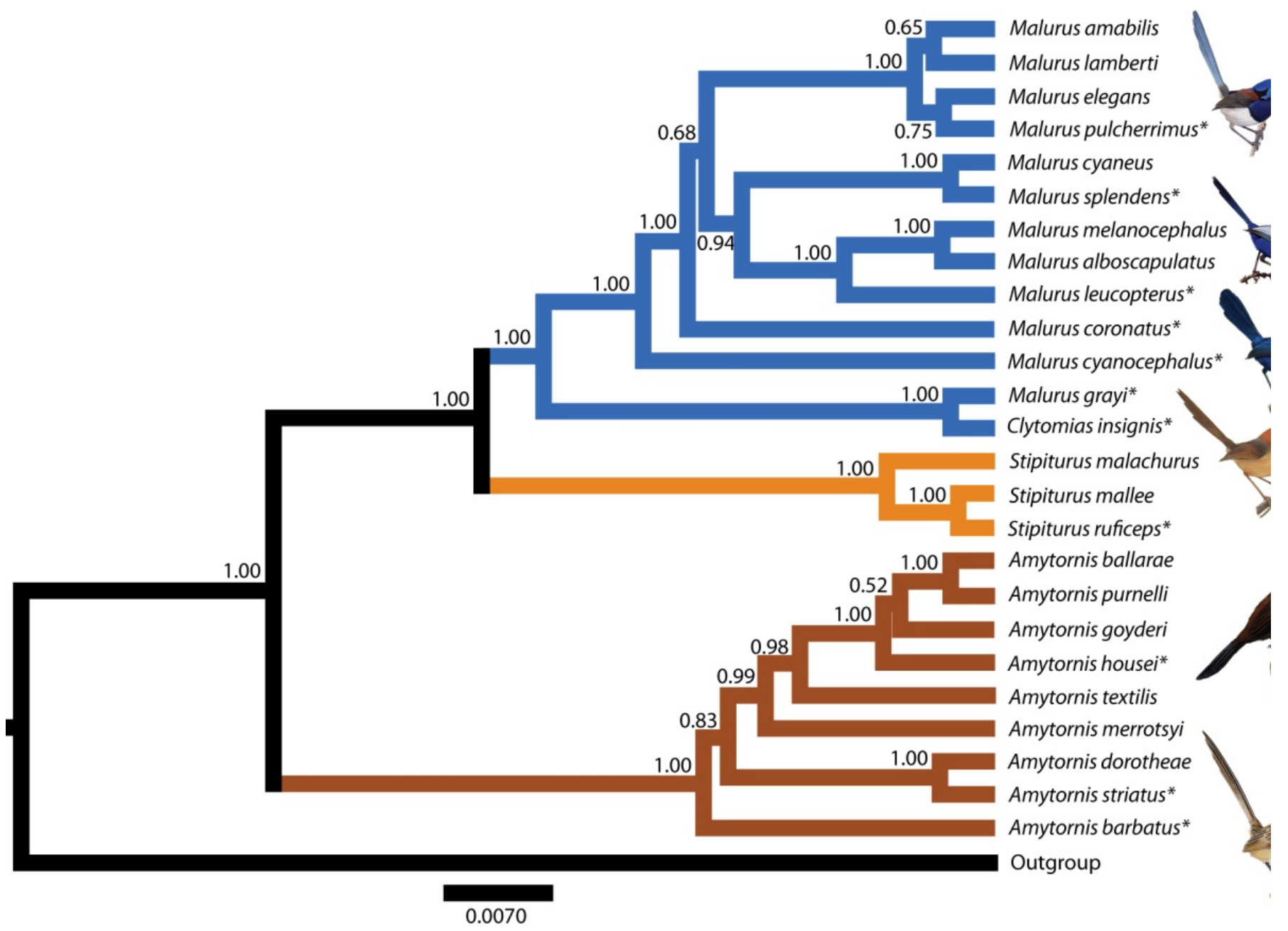




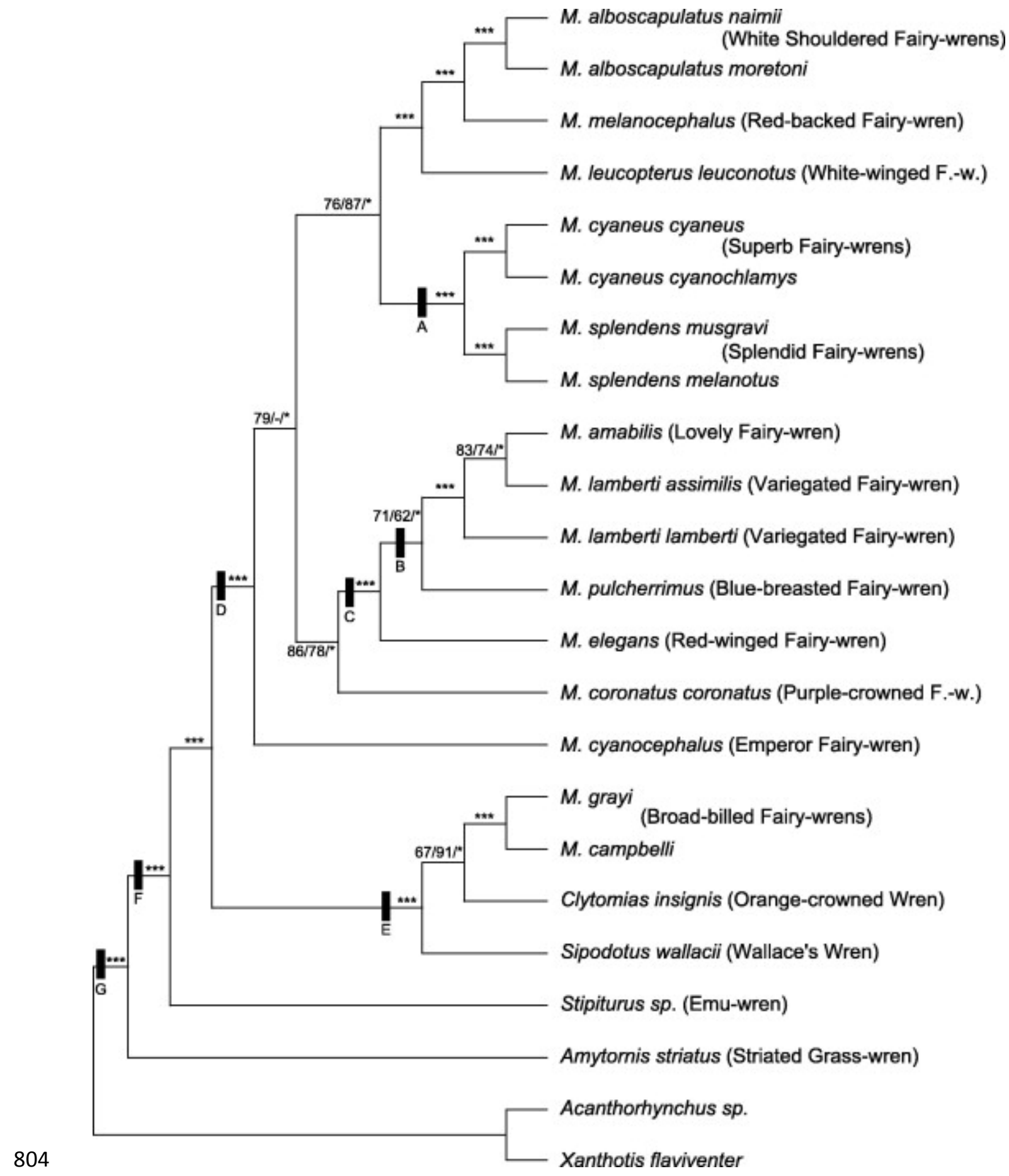


$807 \quad$ Figure 2

808

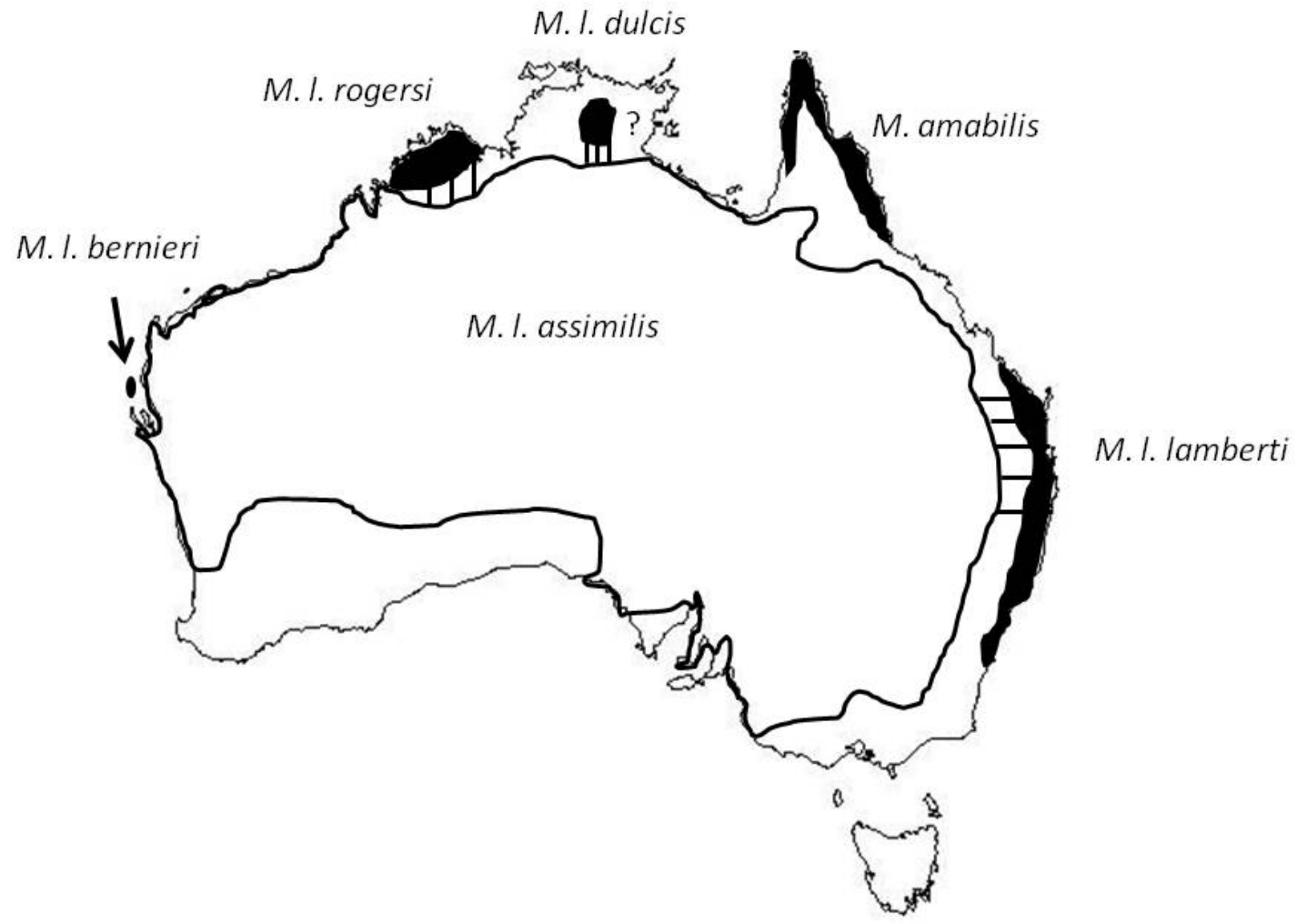


Figure 3
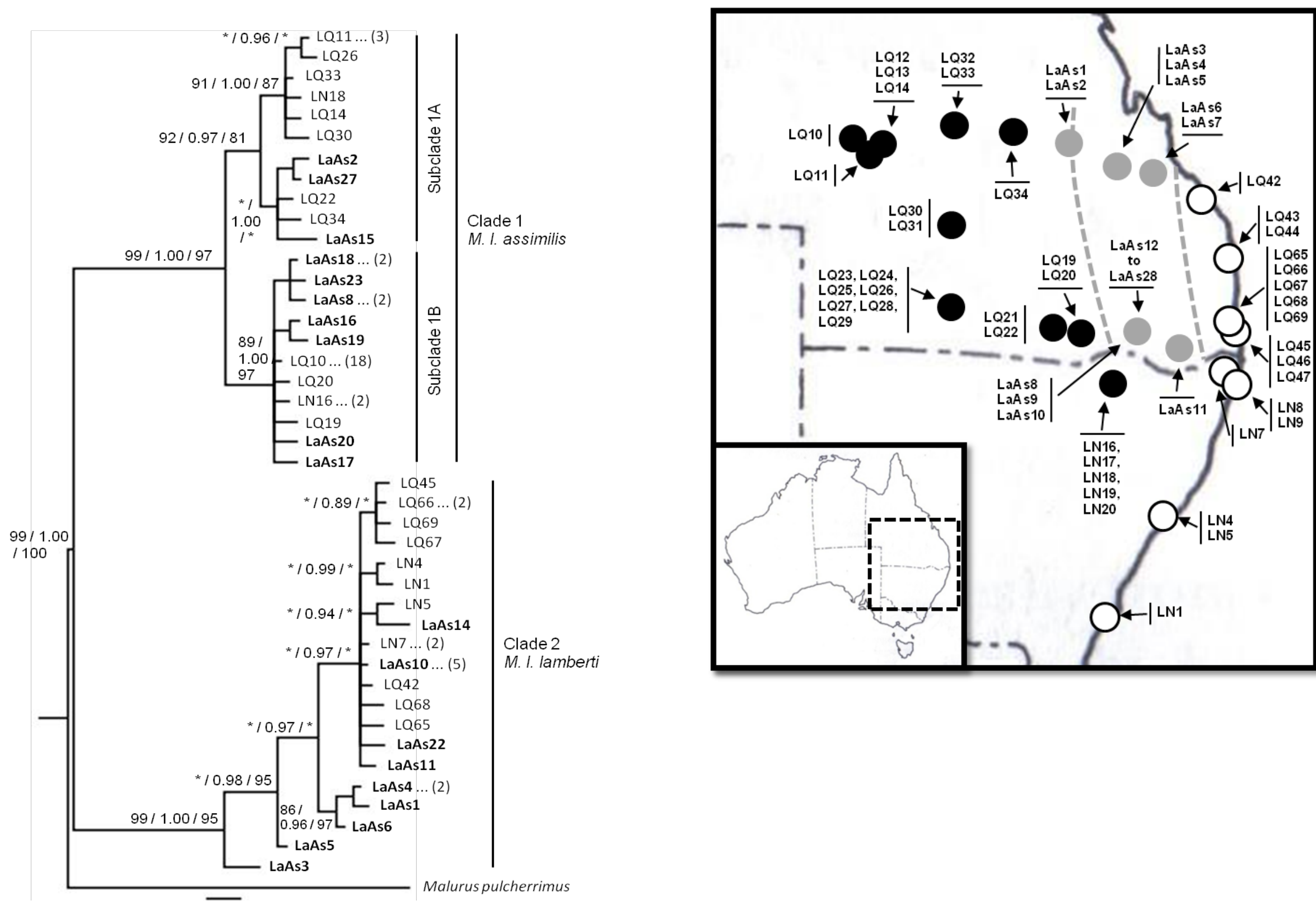
Figure 4

a. Malurus amabilis

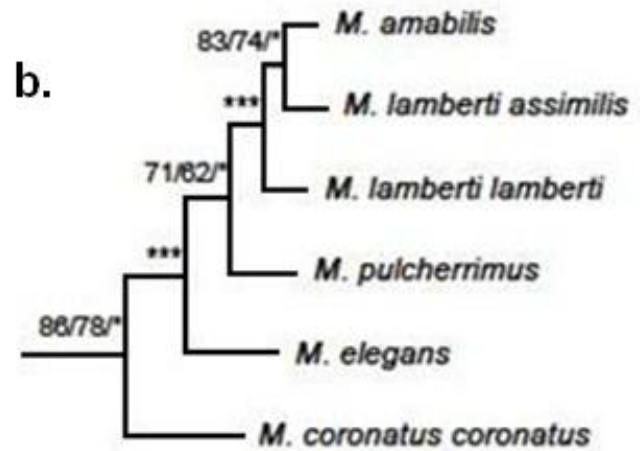




\section{Figure 5.}

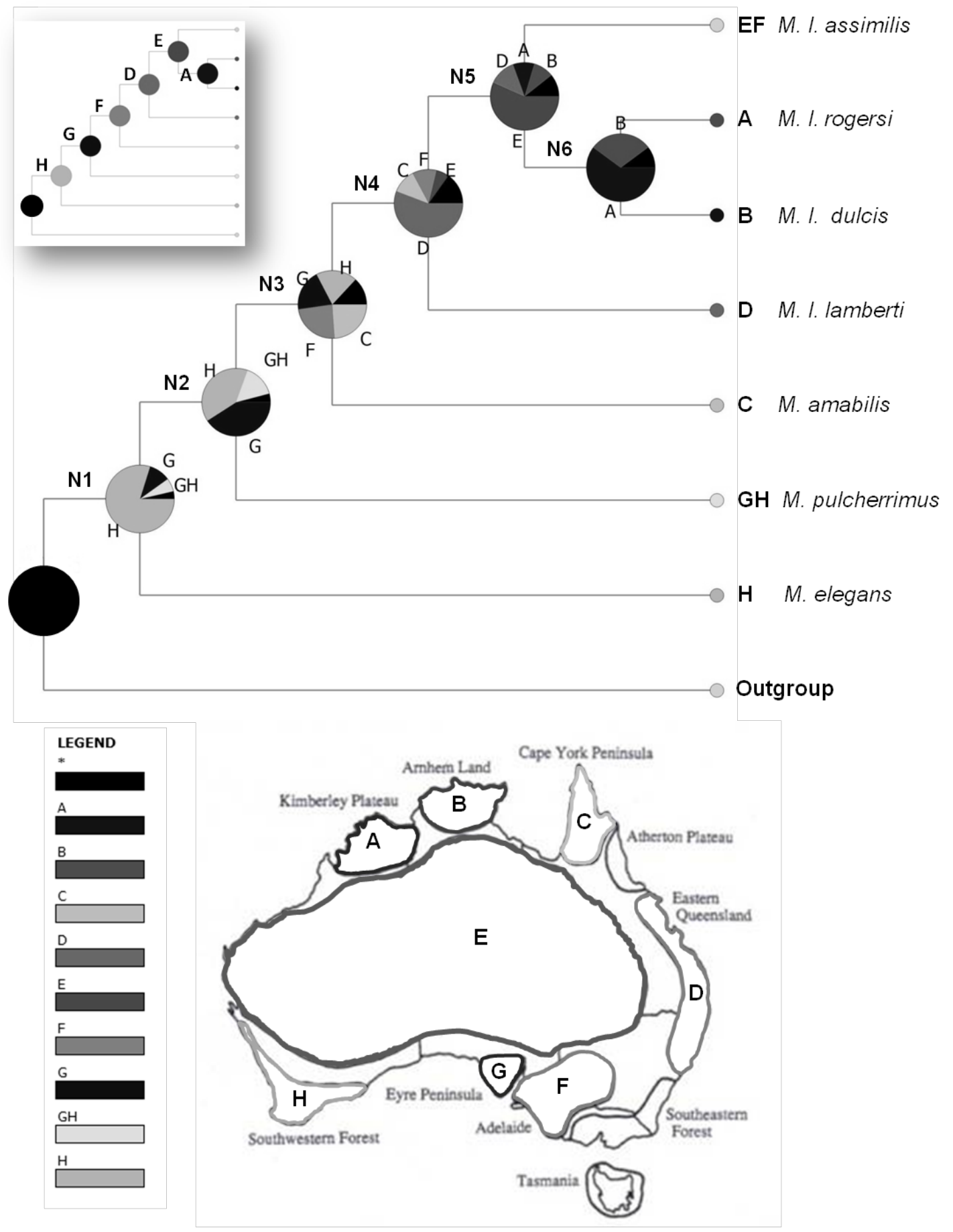

